\title{
Proust - DeManding Reading
}

"A la recherche du temps perdu narrates the flight of meaning, but this does not prevent its own meaning from being, incessantly, in flight.«

Paul de Man: "Reading (Proust) «"

Paul de Man kritiserer i sin indflydelsesrige artikel om Marcel Prousts A la recherche du temps perdu (herefter forkortet ARTP), »Reading (Proust) « fra bogen Allegories of Reading, blandt andre Gilles Deleuze. I sin analyse af ARTP, i bogen Proust et les signes, fors $\emptyset$ ger Deleuze at opstille totaliserende billeder af værket, der ikke tager hensyn til den totalitetsnedbrydende effekt de retoriske konstruktioner hos Proust har, mener de Man. ${ }^{2}$ Deleuze tager nemlig ikke til sidst $i$ sin analyse det samme spring som de Man gør. Han dekonstruerer ikke sin egen læsning, der ellers også kan siges at være en dekonstruktion af teksten som fortalling og som mimetisk refererende til en virkelig verden. Deleuze lægger sin læsning frem, og den kan angribes for den måde, subjektet i tiden tilskrives betydning som den eneste enhed i en verden af kaos.

Deleuzes tanke er, at Marcel og med ham læseren gennemløber en proces, en at læreproces, hvor tegn undersøges i forskellige afskygninger. Det sociale liv, kærlighedslivet, i det hele taget liv fungerer gennem en stadig produktion og udveksling af tegn. Marcel lærer at forholdet mellem tegn og indhold ikke er et stabilt og entydigt forhold, der kan give en absolut viden om verden. På samme måde lærer læseren, at en begivenhed kan betyde forskellige ting afhængigt af, hvornår og fra hvem vi hører om den. Det fænomen, der holder sammen på en verden, hvor tegn og indhold ikke hænger solidt sammen, er for Deleuze tiden. Marcel, og den tid han har levet, er det rum, hvor alle tegn får mening. Ikke entydigt og endeligt, men $i$ en vedvarende proces af vekslende tegn-relationer, der først bringes til en afslutning, når tiden stopper, når Marcel dør. Læseren af ARTP er i læsningen blevet udsat for en prøve på den tegnlæsningsproces, som Marcel gennemlevede, og afkodningen af varket får aldrig ende, det $g \emptyset r$ kun værket.

Hvor de Mans læsning rejser flere spørgsmål, end den besvarer, lægger Deleuze en læsning frcm, dcr beskriver en forståelse af ARTP, der kan bruges 
som inspirationskilde på en række felter. De Man har et stykke værkt $\varnothing \mathbf{j}$, der kan bruges til at afdække en række interessante problemer, men ligeså snart han har gjort det, skynder han sig at undergrave sin egen platform. Deleuze bliver stående på platformen for at afprøve nogle af de læsestrategier, som hans forstảelse implicerer.

De Man har lagt sin forståelse af læsningen som proces frem i en række tekster, blandt andre $\gg$ Semiologi og retorik $\ll$ og $»$ The resistance to Theory «. ${ }^{3}$ Begge steder påpeges læsningens proces som den eneste betydningsskabende. Problemet med de Man er at han, efter min mening, reagerer noget overilet ved at dekonstruere denne proces selv. En liesning af Marcel Prousts $A$ la recherche du temps perdu, der bruger de Mans greb til at åbne teksten, for siden ved en læsning af de tematiske, narratologiske og psykologiske strukturer at undersøge implikationerne af den tekstforståelse, som netop åbnes af de Man, bør give mulighed for at se nye ting i teksten. Og det er, hvad jeg agter at prøve at gøre her.

Jeg starter med at undersøge den store digression i fortællingen som $U n$ amour de Swann udgør. Denne historie bliver fortalt på et tidspunkt, hvor vi ellers er i gang med at læse om Marcels tid i Combray. Fortæelleren er ikke, på samme måde som i resten af ARTP, involveret $\mathrm{i}$ handlingen, da den foregår $f \varnothing r$ hans fødsel. Den kommer derved til at stritte ud fra sammenhæengen på en måde, der påkalder sig opmærksomhed. En opmærksomhed, der synes rimelig, når man senere forstår, hvordan Swann er en eksemplarisk person, som Marcel ofte sammenlignes med. Swann gør sig nogle erkendelser vedrørende sprogets måde at virke på, som fortælleren senere sætter Marcels oplevelser op imod. Marcels oplevelser med erindringen, kærligheden og kunsten påvirkes af sproget på en måde, der ikke umiddelbart er forståelig for ham, men som i fortallingen sætter sig igennem på alle planer, herunder tematisk og narratologisk.

\section{Un amour de Swann}

Un amour de Swann handler om Swanns kærlighed til Odette. Da hun på et tidspunkt får en anden elsker, bliver Swann jaloux, og denne jalousi præger nogle år af hans liv. Swann er kunstinteresseret, hvilket kan spores i hans forståelse af verden og Odette. Det er kunsten og de astetiske udtryk, der spiller den altafg $\varnothing$ rende rolle for de erkendelser han $g \emptyset r$ sig.

Centralt i kærlighedsforholdet står en sonate af komponisten Vinteuil. Den bliver deres »kærligheds nationalmelodi«, og den skifter funktion for Swann fortzellingen igennem. Det er funktioner, der afspejler kerlighedsforholdet, 
Swanns erkendelse af omverdenen, kunsten og sproget. Swann opbygger et tegnsystem omkring sonaten, hvor elementerne skifter betydning $i$ en stadig søgen mod stabile forhold i systemet. Swann gør sig erkendelser om sprogets medierende funktion mellem hans tankeverden og verden omkring ham. Han oplever, at der ikke er en umiddelbar sammenhang mellem subjektet og de fienomener, der omgiver det.

Da Swann i starten hører sonaten sammen med Odette hos Verdurins binder den dem sammen i alles bevidsthed, men Swann har en modvilje mod den, da han ikke finder, at der er en rimelig sammenhæng mellem dem selv og sonaten. ${ }^{4}$ Herefter smelter sonaten sammen med kærligheden. Det er en kærlighed, der ikke svarer til noget ude i verden, men musikken skaber et rum i Swanns sjiel, hvor den giver Odette og hans følelser for hende en substans, som ikke fandtes før. ${ }^{5}$ S wanns besiddelse af Odette giver ham en uro, som han kun kan dulme ved at granske dybere og dybere i hendes væsen. Samtidig ved han, at det vil vare døden for den person, han er og for hans karlighed, hvis han når ned til bunden af Odette og sandheden om hende. Kærligheden og trangen til at finde sandheden er en del af selve Swanns konstitution, som han må leve med. ${ }^{6}$

Swann har allerede i starten set, at der ikke er noget ude i verden, der binder ham og Odette sammen med musikken, men han lader en binding opstå. Forholdet mellem erindringen om musikken og sonaten selv og forholdet mellem følelserne for Odette og Odette selv sættes over for hinanden og kvalitet overføres fra erindringen om musikken til følelserne for Odette, som ved en metaforisk proces. Denne nye binding giver Odette en substans, som er overført fra de følelser, Swann ellers lagde i musikken. For at forstå Odette undersøger han sine følelser og den substans, som Odette har fået, som om det var Odette, der besad denne substans.

Ved musikaftenen hos Saint-Euverte hører Swann sonaten igen, og der sker en forvandling (det ekspliciteres ${ }^{7}$ ). På et tidspunkt, hvor $S$ wann lige har stået og set på de andre herrer og tænkt over, hvordan deres monokler siger noget om dem selv og deres forhold til omverdenen, kommenteres Swanns egen monokel. Fortælleren siger, at $S$ wann ville have tæenkt om sig selv, hvis han havde set sig selv, at han, da han hører sonaten, føler en smerte og stryger monoklen væk fra ansigtet, som var den en plagsom tanke, og tørrer den af, som om han udvisker sorgen. ${ }^{8}$ Swann foler en forvandling, idet han synes, at sonaten kender ham, hans kærlighed og smerte modsat tidligere hvor han havde overvundet det urimeligt subjektive i forholdet." Swann ser, at sonaten er udtryk for hans individuelle opfattelse af lykke og kerlighed, for hvis sonaten kender ham og samtidig er en individuel opfattelse af lykke og kærlighed, må det være ham selv, der har skabt den. På samme tid forstår han, at sonaten ikke bestảr 
af de fem toner, som hans hukommelse havde delt den op i for, at kunne huske den, men er en helhed, som hukommelsen har brudt. ${ }^{10}$

Her fremstår monoklen som et billede på det, der er mellem verden og den, der ser den : perceptionsprocessen. Teksten gør opmærksom på, hvad det er, der er ved at ske, og på sig selv ved at henlede opmærksomheden på en medierende instans på linie med sproget/teksten. ${ }^{11}$ Swann bliver opmærksom på, at han har prøvet at dele verden op i elementer, som ikke i hans erindring kan danne den helhed, de gjorde i virkeligheden. Sonaten er blevet påvirket af hukommelsen på en måde, der understreger det subjektive element, der netop er blevet tydeligt for ham, da han ser, hvor godt sonaten passer på hans følelser, og hvor dårligt den, som han husker den, passer på verden.

Det găr op for Swann, at han har sat Odette og hans følelser for hende over for sonaten og hans erindring om den, og at der derved er skabt sammenhænge mellem fænomener, hvis eksistens beror på de enkelte elementers stabilitet. Da Odette kom til at hrenge sammen med erindringen om sonaten og sonaten kom til at hænge sammen med følelserne for Odette, er hele systemet nu i fare, idet han ser, at hans erindring orn sonaten ikke passer på sonaten, som han nu hører den. Han får mistanke om, at Odette ikke passer på det billede, han har af hende, og at hans følelser for hende ikke passer på den person hun er. Han hører nu i sonaten dialogen mellem pianoet og violinen, og hører et sprog, der er meget klarere end det talte, netop fordi det ikke er det talte. ${ }^{12}$ Der er i musikken en mulighed for at danne et sprog, hvor tegn og betydning er lig hinanden, og hvor verden derfor stăr klart frem, men det er et sprog, der kun gælder for de to, der er forenet i sonaten. Forskellen mellem musik og sprog er, ifølge maleren Elstir, der optræder hos Verdurins, at i musikken er galskaben og manglen på logik konstituerende elementer, mens sproget vil afsløre den talendes galskab. ${ }^{13}$

En dame siger til Swann efter musikken, at hun aldrig har oplevet noget lignende siden hun overværede en aften med »table tournante $\ll .{ }^{14}$ Han noterer sig, at hun siger en ting, og at han selv forstår noget andet og dybere ved det. Han læser en anden mening, der måske er mere bogstavelig, end den damen $\emptyset n s k e d e$ sig at lægge frem. Damen taler om et begreb, der henviser til okkulte fænomener, mens Swann læser en mere bogstavelig betydning ud af ordene. Han oplever at bordet vender, meningen skifter, at hans liv ændrer sig fra dette øjeblik. Ordet trope er involveret på fransk idet »tropein«betyder at dreje, og det er netop tropen, der i dette tilfælde er ustabil og derved afslører sit fundament. Tegn og betydning hænger ikke sammen på en universel måde. Det ekspliciteres, at det var en afgørende aften i Swanns liv, og det găr op for ham, at Odettes kærlighed til ham aldrig skal realiseres, undtagen i ham selv. ${ }^{15}$ Sprogets upålidelighed understreges ved denne erkendelse, der ikke er gjort, fordi 
damen sagde noget klogt, men fordi Swann selv foretager en kobling mellem ord og mening, tegn og betydning, en kobling som ikke falder damen selv ind, da den jo angår Swanns personlige og intime liv.

Swann har af damen fra selskabet hos Saint-Euverte faet henledt sin opmærksomhed på sprogets evne til at vende rundt på tingene og til at skabe ustabile forbindelser mellem tegn og betydning. Det berører alle livets forhold og i særdeleshed hans forhold til Odette, som han derfor opsøger. Han presser hende til at give oplysninger om sit tidligere liv og om sine andre forbindelser. Afsløringerne rører ham nærmest fysisk i hjertet. Det hun fortæller ligger så langt væxk fra de værste tanker, han havde gjort sig, virkeligheden så langt væk fra hans vierste fantasier, at han igen kommer til at tenke på damens udbrud on »table tournante $\ll .{ }^{16}$ For anden gang vendes der op og ned på hans forestilling om verden. Swann mente at kende Odette, men hun viste sig at være en helt anden; hans forstålse af hende viste sig at viere domineret af hans egne projektioner. Han har begæret en sammenheng, og da den ikke fandtes, har han skabt den selv. Den betydning, han havde liest af tegnet Odette, havde intet at skaffe med den virkelighed, Odette selv kunne fremlægge, ligesom sonaten ikke passede på erindringen om den.

Riekkevidden af de konsekvenser det har for hans liv, at hukommelsen fungerer, som den gør, går op for ham. Ikke engang Odette kender han. Forholdet mellem musikken og Odette, set gennem Swanns kærlighed til hende, og forholdet mellem Odette og Swann er skabt på et usikkert grundlag. Hverken tegnet eller betydningen er faste, stabile enheder, der kan forstås og huskes, og forholdet mellem dem er ligeledes usikkert.

Swann har giort sig nye erkendelser med hensyn til sin forstålse af omverdenen og de forhold, der styrer denne forstảelse. Sproget og den forståelse, det bibringer ham af omverdenen, er begrienset af den form, der liegges ned i erfaringen ved sprogets verbalisering af den. Formen var hans subjektive fortolkning, som han snød sig selv til at se som objektiv sandhed. Det har haft konsekvenser for Swann, hvis liv var et mareridt i flere år »alt sammen for en Kvinde, som ikke faldt i min Smag, slet ikke var min Type (...) s, som han siger til sidst. ${ }^{17}$

A la Recherche du Temps perdu er som helhed en sproglig, narrativ gengivelse af et levet liv, og som sådan må det vare præget af den måde, en sproglig form saetter sig igennem på. Hvis man lieser Swanns kcerlighedshistorie, som jeg her har gjort, kan man se den som en problematisering af værket som sådan, af sproget og af erfaringen. Der er ingen fast betydning at finde noget sted, og intet stabilt forhold mellem et tegn og den betydning den enkelte udleder af det. 
Swanns erkendelser er allerede gjort, før fortxlleren bliver født, og da fortælleren er barn, er Swann blevet gift med Odette. Swann har altså gjort sig nogle erkendelser, og har senere handlet med disse i baghovedet. Det undrer $i$ første omgang læseren at høre, at $S$ wann er blevet gift med Odette, men forklaringen kommer i forbindelse med Marcels møde med Elstir. ${ }^{18}$ Fortelleren bruger smagen af en kage som påskud for at huske sin barndom i Combray og begynder at fortæelle hele sin livshistorie. Digressionen, fortælleren $\mathrm{g} \emptyset \mathrm{r}$ meget tidligt i fortællingen for at fortælle om Swann, må så vidt jeg kan se have en vis betydning for forståelsen af resten af fortiellingen. Swanns måde at erkende og handle på er en blandt flere, men da den drejer sig om sproget, erfaringen og fortællingen, sætter den resten af historien i relief. Den helhed, som Swann ikke kunne skabe i sin hukommelse af musikken, kan man betvivle, at fortælleren kan skabe i sin jagt på den tabte tid, idet det netop er den konstituerende del af helheden, der ikke findes mere: tiden selv.

Jeg har søgt at vise, hvordan et tropologisk betydningsskred i de centrale strukturer, der i historiens l $\varnothing$ b virker som bindemiddel mellem Swann og Odette, ved en nærlæsning viser sig ikke at kunne holde sammen på noget, strukturer der overførte vardier fra et felt til et andet og derved fik dem til at hænge sammen. Men det skete på et grundlag, der ikke selv var helt stabilt eller værdifrit. Det er sprogets måde at fragmentere verden for derefter ved en længere og for den enkelte helt uklar proces at binde den sammen i nye kombinationer på en »naturlig « mảde, der diskuteres. Det viser sig, at subjektet selv har den altafgørende indflydelse på, hvordan verden ser ud. Afkodning og betydningsdannelse skaber selv værdier.

Når Paul de Man i sin artikel, som jeg kort præsenterer nedenfor, viser, hvordan metaforer ikke er metaforer, men snarere metonymier, er det det samme. ${ }^{19}$ Det er helheder, der bygges op i sproget som følge af et ønske om totalitet og forståelighed hos Marcel og den læsende, der nedbrydes igen ved modsatrettede udsagn i teksten. Det gør nærhedsrelationerne til de eneste betydningsskabende. Totaliteten er væk. I ARTP bliver disse erkendelser ikke bare stảende og flagrer. De bliver diskuteret og perspektiveret i forhold til Marcels oplevelser med erindring, kærlighed og kunst. Herved udbygges diskussionen til at implicere en række eksistentielle fænomener, der foruden at forholde sig til »almindelige « menneskelige vilkår, kaster nyt lys over sprogets funktion. Før jeg går videre med min analyse, vil jeg præsentere de Mans læsning lidt mere udførligt. 


\section{Paul de Man}

Paul de Mans projekt går ud pâ at finde spor i teksten, der siger noget om læsning. Han unders $\emptyset$ ger, hvordan læsning skal foretages, og hvilke betydninger man kan udlede af teksten. ${ }^{20}$ Han går ud fra en tese om, at man starter læsningen i en tro på bogstaveligheden, tekstens evne til at sige noget med direkte henvisning til en virkelighed. Men denne tro står $\mathrm{i}$ et spændingsforhold til en skepsis over for tekstens evne til at kommunikere mening. Ud af denne tvivl opstår den frugtbare liesning.

De Man analyserer med dette udgangspunkt forskellige afsnit i ARTP, der på den ene eller anden måde relaterer sig til det at lixse. I Ian viser, hvordan teksten opbygger kæder af modsætningspar, hvor parrene udveksler kvaliteter, og nye par opstår. Men modsætningsrelationerne opløses, og betydningen glider. Tekstens forsøg pả tegne et billede ved hjælp af metaforisk overførsel af værdi mellem kieder af modsætningspar viser sig ikke at viere solidt funderet. ${ }^{21}$ Dette leder de Man frem til at spørge om, hvordan det kan vere, at troperne kan opbygge et univers, hvor sandt og falsk kan bytte plads, som de tilsyneladende gør m.h.t. kæderne af modsretningspar, uden at man lægger mærke til det. Han mener, at det er karakteristisk for tropologiske systemer i almindelighed, at de betjener sig af substitutioner og udvekslinger af enheder og værdier.

I et afsnit af ARTP, hvor Marcel søger skjul for at kunne lase i fred, fremanalyserer de Man igen to kæder af modsætningspar, der påvirker hinanden på forskellige måder. To umiddelbart uforenelige værdisæet forenes ved hjelp af tropologiske processer. Ydre og indre, lys og mørke, kulde og varme, læsning og aktivitet bringes til at udskifte kvaliteter med hinanden. For Marcel har det den funktion, at han med god samvittighed kan sidde og læse, uden at få det dårligt over ikke at honorere bedstemoderens krav om aktiv leg uden for huset. For de Man betyder det, at teksten betjener sig af figurer, der tilsyneladende er naturgivne eller nødvendige for at overbevise Marcels samvittighed og laseren. Han mener, at en tematisk liesning af en passage som denne ville vare nødt til at lage tekstens værdistruktur bogstaveligt og betjene sig af de metaforer, der skabes, for at kunne fremlase nogen betydning. Men idet metaforerne ikke er stabile enheder, der kan frembringe entydige budskaber, fordi sammenknytningen af elementerne ikke er naturgiven, ville en sådan læsning være ubrugelig. 22

Det, der står på spil i forbindelse med brugen af metaforerne, er en forening af Marcels indre liv og hans ydre verden og korresponderende hertil en forening af tekstens verden og verden omkring den. Men de Man mener, at der er samme ustabilitet i begge forhold, som han har afsløret i forholdet mellem 
indre og ydre verden hos Marcel. For en læser, der reagerer på de æstetiske virkemidler, som teksten tager $i$ anvendelse, og lader sig overbevise af metaforernes forening af modsatrettede krafter, kan der opstå en ligeså overbevisende betydning ved, at han følger et andet spor, som teksten lagger ud, og herved opstår en kløft. Den anden læsning, som teksten lægger op til, ifølge de Man, er en læsning, der er følsom over for de retoriske strukturers svagheder. Det er svagheder i metaforerne, som de Man fremanalyserer, og finder belag for $\mathrm{i}$ tekstens selvrefererende passager, hvor fortælleren reflekterer over forholdet mellem ting og de ord, som man betegner dem med, og som viser sig at ophobe en mangde følelser, der ikke findes i tingen selv. ${ }^{23}$

Disse to læsninger er helt uforenelige, men lige overbevisende. Spørgsmálet er nu, om der er mulighed for at have dem begge i en læsning, der så svinger mellem de to som mellem sandt og falsk. Derved ville teksten komme med et grundlag for sig selv, hvorpå den ville kunne forstås. Nemlig som en lasningens allegori, der demonstrerer enhver liesnings problem, det referentielle forhold mellem tekst og verden. ${ }^{24}$

For at unders $\varnothing g e$ om der kunne vare fornuft $i$ at tale om en stabil allegorisk liesning af teksten som spendt ud mellem to punkter, finder de Man nu et sted hos Proust, hvor allegorien behandles, nemlig i forbindelse med Marcels refleksioner over et billede at Giotto. ${ }^{25}$ Det interessante ved billedet er, at det er en allegorisk fremstilling af en handling, som man kan identificere, men samtidig giver billedet en rakke andre udsagn fra sig, som forstyirer det allegoriske budskab. Der opstår en kamp mellem en afkodning af billedets metaforer og en allegorisk fortolkning af det, hvor læsningen af billedet selv vinder $i$ Marcels tolkning. Billedets titel, der er skrevet med stort på rammen, henviser til den allegoriske betydning, og det er kun fordi den er fremhevet her, at man kan lase allegorien. Billedet forestiller en kvinde, der rakker en genstand op i luften. Hendes fysiske fremtræden og hendes bevægelse konnoterer for de Man betydninger, der afviger fra den allegoriske, som maleren legger op til ved at skrive »Caritas « på billedets ramme. Ved at lade billedet tale for sig selv havde maleren tvunget beskueren til at sæatte gang i en afkodningsproces, der ville have omformet en billedmetafor til en bogstavelig betydning, der ville forblive implicit, idet den ville være konstitueret af selve billedet. Men ved at give et bud på en lessning på rammen kommer den metaforiske og den allegoriske læsning i kamp, da de ikke frembringer den samme betydning. Samtidig sammenkobler billedets titel billedets motiv med begreber og fienomener, der findes uden for billedet selv. På denne måde forankres billedets betydning i den »virkelige« verden uden for billedet og ikke i de interne strukturer, som giver den betydning Marcel først laser frem. 
Man kan ikke på samme måde skrive »læs ! « på siderne i Prousts bog, for lasningen af bogens liesningens allegori har ikke en reference til noget uden for teksten som billedet har. Mens billedet henviser til et empirisk fienomen, der giver det en betydning, som rekker ud over billedet, henviser tekstens allegori kun til teksten selv og til forstảelsen af den. De betydninger som teksten indeholder yå det allegoriske plan vil derfor også gælde selve liesningen. Den mening som teksten fremliegger, vil bestandigt afvige fra selve lesningens kurs mod en forståelse. Denne proces er uophørlig. Teksten vil altid kalde pá fortolkning og på samme tid vil den gøre den umulig. ${ }^{26}$ Det er på baggrund af denne lesning, at de Man kommer frem til sin konklusion, som jeg citerede indledningsvis. ARTP handler om betydningens flugt. Men pả samme tid er dette udsagn selv underlagt betydningens flugt.

Noget af det, de Man glemmer i sin analyse, er, at lasning ikke er en objektiv afkodningsstrategi, men derimod en subjektivt styret proces. Ingen mening kan findes, hvis man med lesning forestiller sig en subjektløs konstruktion. Swann oplevede, at der ikke var nogen sandhed i verden, der svarede til hans, og på samme måde oplever Marcel, at der ikke er noget i verden, der svarer til ham. Derimod er der en liesning af verden, som fremstår som en ophobning af erfaring over tid. Det er kun ham, der forankrer denne ophobning, og det er kun ham, der har adgang til den. Det vil jeg prøve at vise.

\section{Erindringen. Madeleine-kagen}

Når Marcel tenker tilbage på den tid, da han lå søvnløs om natten, husker han, at han altid mindedes sin barndoms Combray på en bestemt måde. Alle detaljer var vak, og kun nogle få elementer var fremme i bevidstheden. Det var muligt at trakke flere frem, men der var et meget dominerende billede af et bestemt klokkeslet, et bestemt hus, et bestemt lys. Alle indtrykkene omkring det daglige »gå-i-seng-ritual « er samlet og udgør mindet om barndommen. ${ }^{27}$ Han kan godt huske andre ting, og han er ogsả bevidst om at der var andet $\mathrm{i}$ barndommen end lige denne hverdagsbegivenhed, men det er svart at få kaldt det frem, og det savner sammenhieng og substans, når det lykkes.

Marcel husker en keltisk myte om, hvordan ting kan opsuge essensen af de begivenheder og de personer, man oplever $\mathrm{i}$ tingenes nærhed, og h vordan et tilf:eldigt møde med disse ting senere kan genkalde fortiden i os selv. På samme måde sker det for ham, at han ved et tilfaldigt mode med en kage og en kop the erindres om sin barndom. Kagen han spiser, kalder en fø̆lelse frem $\mathrm{i}$ ham, som er forbundet med barndommen, men som har en helt anden natur. Den materielle kage giver en sanseoplevelse, der er forbundet med en følelse 
af glæde, og denne følelse af glæde korresponderer, går det op for ham, med en lignende følelse af glæde, som han oplevede i sin barndom. Smagen af the og kage minder ham om søndag morgen, hvor han gik op til sin syge tante, og der fik the og kage. Spæendet mellem den positive morgenoplevelse og den dominerende erindring om aftenritualet får nu hele den tid frem i klare billeder komplet med huse, personer, oplevelser og følelser. Det hele folder sig ud i bevidstheden. Når han tæenker over det, har han tit set disse kager, men det er den specielle smagsoplevelse af the og kage, der vakker mindet. ${ }^{2 *}$

Marcels oplevelse med kagen, der vækker minder, er en kæde på mindst syv led, selv om det umiddelbart ser ud, som om der er en direkte vej fra kage til erindring. Leddene skifter mellem at være billeder, følelser og sanseindtryk. Det hele begynder med smagen af the og kage (1), der fremkalder en følelse (2) i ham, som han ikke kan placere, men han fïnder ud af, at den korresponderer med en tidligere følelse (3), der igen hæenger sammen med en tidligere smagt kage (4). Denne kage er knyttet til bestemte oplevelser og følelser (5), som han har haft sammen med sin tante. Disse erindringer åbner det kondenserede billede (6), som han havde af aftenritualet i Combray, og den fulde erindring om Combray folder sig ud (7).

Oplevelsen med Madeleine kagen er central for forståelsen af Marcels forhold til omverdenen. Det vigtige er den måde, hvorpå en erindring bindes sammen med et konkret faenomen. Noget så prosaisk som en kage, som alle franske børn kender, bliver bragt til at bære en erindring så omfattende som den, der indeholder hele barndommen, og derved sætter gang i den proces, der til sidst i fiktionen får Marcel til at sxette sig for at skrive, det man kan formode er ARTP.

\section{Karligheden. Bondepigen}

På Marcels spadsereture i landskabet rundt om Combray gør han sig nogle tanker om sin måde at opfatte naturen på. ${ }^{29}$ Han er begejstret for at gå alene rundt $\mathrm{og}$ se på landskabet, men han føler en heftig trang til at omfavne en bondepige. Det er ikke en konkret bondepige, han har mødt, men én han fantaserer om at møde. Begaret efter hende er udtryk for den samme følelse i ham, der bearbejder og glaedes over de mange indtryk, naturen giver ham. Oplevelsen af naturen og begæret efter pigen smelter sammen, og det begrænsede $i$ pigens skønhed tilf $\emptyset$ res kvaliteter fra den rigdom, han finder i naturen. Han føler, at pigen besidder naturens kvaliteter, og at en erotisk forening med hende vil give mulighed for, at han kan få essensen ud af omgivelserne, og af de bøger han har læst. De oplevelser, han fär af at være i verden, vækker i ham et 
stærkt, nærmest erotisk begær efter at optage verden i sig eller at gennemtrænge den. Men den måde verden og begæret udveksler kvaliteter på, tyder på, at han forveksler eller sammenblander verden med begaret efter den.

Marcels fantasi făr nye krafter ved forbindelsen med sanseligheden, og han føler, at der er en naturgiven og nødvendig sammenhæng mellem den natur, han befinder sig i, og de mennesker, han kunne tænkes at møde der. Fortælleren reflekterer i tilbageblik over, at man føler livet mere virkeligt og umiddelbart i sin ungdom. ${ }^{30}$ Denne følelse af nærvar skyldes den følelse af nødvendighed, der ligger i sammenhængen mellem natur og menneske. Begæret efter denne meningsfulde sammenhæng får ham til at indse, at hvis han selv havde skabt sammenhæengen eller ændret på den, ville den ikke være noget værd. Hvis han havde mødt bondepigen i Paris, ville det ikke være det samme, da hendes kvalitet afhænger helt af den natur hun færdes i, og hvis kvaliteter hun er blevet tillagt. ${ }^{31}$

Tanken om, at pigen ikke vil komme, piner ham, da hendes fravær vil berøve ham muligheden for at lære egnen og naturen at kende til bunds. Hun er en lokal $» v æ k s t \ll$, der er ene om at kunne give adgang til sandheden om egnen. En refleksion pá dette sted indskyder, at begæret efter en bestemt kvinde, efterhånden som livet går, transformeres til et mere alment begxr efter kvinder, da det går op for en, at den nydelse, hver enkelt kvinde giver, er pracis den samme, som de tidligere har givet. Forholdet til kvinder udvikler sig også ved, at der opstår en »besiddelsesglæde«, hvor det eneste, man tænker på, er kvindens skønhed og den fortryllelse, den udøver over en. Hver gang et begær opfyldes i forholdet til cn kvinde, bringer det kun andre glæder i erindring, og det ender med en voldsom følelse af ens egen taknemmelighed over kvindens godhed. ${ }^{32}$

Historien om bondepigen tager hul på et genkommende tema i ARTP, nemlig kxrligheden. Her bliver den som så mange andre gange koblet sammen med et begær efter mening. Begæret efter at forstå verden og at indoptage dens essens er meget heftigt i den unge Marcel, og den erotiske læengsel efter bondepigen er et begær efter at finde en vej til en mening. Pigen udveksler kvaliteter med den verden, hun skal give adgang til, og de bliver uadskillelige for Marcel. Den naturgivne sammenhang, han føler, der er mellem dem, bliver afløst af en tvivl. Det sker ved, at han dels ser, hvordan konteksten spiller en afgørende rolle for hendes kvalitet, og dels indser, at pigen ikke vil materialisere sig i naturen, og at han derfor bliver tvunget til at opgive den absolutte mening, verden ville få, hvis hun havde materialiseret sig for ham. Den retrospektive fortæller udbygger denne tvivl til et vilkår, som man erkender med alderen: Begæret efter kvinder og den mening de kunne give almengøres til et mere abstrakt ønske om mening. Endvidere peger fortælleren på, at man efter- 
hănden udvikler en taknemmelighed, der opleves som den dominerende $f \varnothing$ lelse, når begæret opfyldes. En taknemmelighed der viser, at det måske snarere er kvaliteter ved ham selv end ved hende, der træeder frem. Når den dominerende følelse er, at hun $g \varnothing r$ noget for ham, i stedet for at gøre noget for dem begge eller bare for sig selv, må det betyde, at den mening der er/kunne være i forholdet, kommer fra ham selv. Marcels tvivl bestyrkes til vished, da han overvejer, hvordan en virkelig bondepige ville have reageret på et forslag fra ham. Han er selv sikker på, at hun ville have anset ham for at være gal, at hans lyst er helt subjektivt baseret og ikke rationelt forankret i verden. ${ }^{33}$ Det får ham til helt at miste troen på sammenhæeng, og historien om bondepigen slutter med, at han fraskriver den konkrete verden enhver mening, idet han sammenligner den med kupeens betydning for handlingen i den togrejsendes bog. ${ }^{3.4}$

Der opstilles her to diametralt modsatte opfattelser af forholdet mellem et indre tankeunivers og en ydre fysisk virkelighed i fortællingens tid, men fortælleren reflekterer over hæundelserne og făr dem til at fremstå som de første erfaringer $\mathrm{i}$ en række, på baggrund af hvilke han allerede kan opstille nogle konklusioner. Marcel afskriver muligheden for at skabe mening gennem bondepigen, mens fortælleren almengør Marcels erfaringer og lader ane, at der skal en hel del lignende erfaringer til, før der kan skimtes en sammenhæng mellem kvinderne og begæret efter mening i verden. Herefter vil Marcel så kunne se, at der ikke er rimelighed i lignelsen, men at sammenhængen heller ikke er umiddelbar og enkel.

\section{Kunsten. Mфdet med Elstir}

I Balbec opsøger Marcel maleren Elstir. Mødet giver anledning til en række refleksioner over forholdet mellem et (selv)erkendende subjekt og verden. Før sin samtale med Elstir ser Marcel atelieret som et »laboratorium «, hvor maleren sætter verden sammen på nye og anderledes måder, efter først at have taget elementerne ud af deres ellers kaotiske sammenhæng. ${ }^{35}$ Han navngiver verden pả en ny måde og herved forvandles den. Processen sammenlignes med den, der i sproget skabes af metaforen. ${ }^{36}$ Marcel siger om billederne:

$\gg[$... j jeg kunne deri se, at hver enkelts charme bestod i en art metamorfose af de fremstillede ting, analog med den man i poesien kalder metafor, og hvis Gud Faderen havde skabt ting ved at navngive dem, var det ved at andre disse navne eller ved at give dem nye navne, at Elstir genskabte dem. $\ll^{37}$ 
I citatet bruger fortæelleren/Marcel en metafor for at anskueliggøre et synspunkt. Men det er netop en metafor, for der er afgørende forskel på en sproglig og en visuel fremstilling af verden. Det er ikke sådan, at tingene har navne, og at det er dem, man cendrer, når man maler. Det er en visuel oplevelse af verden, der består af på den ene side en oplevelse af en materiel virkelighed og på den anden side et malet billede, skabt af den, der har set/fortolket den materielle virkelighed. Pả samme mâde kan man sige om sproget, at det fordrejer virkeligheden efter det subjekt, der ser og udtrykker et indtıyk. Teksten reflekterer her sin egen virkemåde og funktion ved dels at tale om metaforen som meningsbærende og producerende, dels ved i beskrivelsen af billederne at iscenesætte en metaforisk drejning, der anskueliggør det helt subjektive islæt, der prager denne drejning.

De navne, man har givet fænomener i verden, svarer ikke til det indtryk, man har, men er en »forstandsmessig « opfindelse. Marcel husker, hvordan han kan ligge på sit værelse på hotellet i Balbec og se ud af vinduet og opleve, at han ikke altid kan skelne himlen fra havet. De to elementer er smeltet sammen i et kort øjeblik, hvorefter han ved forstandens hjeelp kan skille dem ad. Formen er forsvundet, kun det rene indtryk er tilbage. Det bringer ham til at skelne mellem den »rene« oplevelse og den af bevidstheden bearbejdede og navngivne oplevelse. Han valoriserer den »rene« oplevelse højest, og det fär ham til at mene, at en "poetisk « oplevelse af verden giver mulighed for at se verden, som delı er: »[..] de sjældne øjeblikke, hvor man ser naturen som den er, poetisk, det var dem, der udgjorde Elstirs værk. "s ${ }^{38}$ Teksten kommer med to diametralt modsatte synspunkter pả én gang. Poesi er, har vi lige med metaforens hjelp fået vist en drejning af verden. Marcels tanker om den rene erkendelse, der viderebringer verden som den er, demonteres. En demontering, der underbygges i løbet af besøget, hvor han reflekterer over den metaforiske betydningsdannelse i Elstirs billeder.

For kunstneren er valget af materiale ikke tilfældigt. Verden afbildes ikke bare. Der sker fra kunstnerens side en udvalgelse af elementer i verden, der på forhånd kan siges at ville tilfredsstille hans trang til selvudfoldelse. Elementerne opfylder visse æstetiske kriterier og bearbejdes intellektuelt, før de sættes på larred eller papir. Her er nemlig tale om en proces, der er falles for maleren og romanforfatteren. ${ }^{30}$ For begge gielder det tilsyneladende ogsă, at de dvaler ved fænomenerne i verden i stedet for at omsætte dem til kunst, som om verden i sig selv indeholdt noget af kunstvierket.

Det gør den naturligvis ikke. Efter det vi lige har været igennem, kan man tro, at der er tale om en dovenskab, som når Elstir finder ro ved at betragte sin kone som et kunstværk. På samme måde blev Swann doven. Det bemærkes, at Elstir kommer til et punkt, som af ham selv eller fortielleren kaldes »livets 
skønhed « og er det sted, hvor man i verden ser opfyldelsen af de æastetiske idealer, man har. Det bliver med alderen et sted, man vender tilbage til. For Swann var det stedet, hvor han resignerede og blev stående:

»..livets skønhed, på sin vis et betydningsløst begreb, et stadie før kunsten, hvor jeg havde set Swann standse, var stedet, hvor det kreative geni aftager, og hvor Elstir, forguder af sine ynglingsformer som han var, efter ønske om mindre slid ved arbejdet, en dag skulle rykke ned. $\ll^{4 \prime \prime}$

Ånden bliver doven og søger at undgå de abstraktioner der ville kunne fortælle, at der ikke er en direkte sammenhæeng mellem et indre ideal og verden.

Når verden ikke hænger sammen med subjektet, og subjektet ikke hrenger sammen med sproget, og sproget ikke hænger sammen med verden, hvad er det så, der holder verden sammen og muligg $\emptyset$ r Marcels eksistens? Det totaliserende billede, man som læser danner af den masse af oplevelser, som er Marcels liv er på alle planer blevet nedbrudt, og der er kun tre adskilte, men dog uadskillelige størrelser tilbage. Efter at være gået ud over det punkt. hvor en de Man-læsning ville være stoppet, er vi nu kommet til næste fase. Den tematiske lasning af Marcels oplevelser underbyggede den indledende læsning af Swanns karlighedshistorie. Subjektet, verden og sproget hrenger ikke sammen på en objektiv verificerbar måde, men når man forholder sig til erindringen, kærligheden og kunsten får man opstillet forskellige billeder af de faktorer, der er med til at knytte subjektet til sproget og dermed til verden.

\section{Tiden}

ARTP er bygget op omkring episoden med Madeleine-kagen, og her ser det umiddelbart ud til, at man kan tale on en direkte relation mellem objekter $\mathrm{i}$ verden og subjektets indre, herunder erindringen. Det viser sig dog, at der ikke er tale om en direkte forbindelse, men at der på vejen mellem subjekt og objekt foregår en række processer, der bearbejder det endelige indtryk eller udtryk. Den medierende faktor er ikke neutral. Sproget er ikke blot et transportbånd for betydningen. De tre temaer erindring, kærlighed og kunst fik nye niveauer frem, der hver isar er betydende for processerne mellem Marcel og verden: begar efter erkendelse og kvinder; perspektivets betydning i forhold til verden, tiden og begaret; sproget, herunder dets funktion, formidlingsproblemer, begæret efter verden og perspektivet igen.

På disse tre niveauer, der som det ses også er sammenflettede, demonteres en umiddelbar lasning af de analyserede passager, ved at forskellige syns- 
punkter trækkes frem samtidig. Det lidt forvirrende ved teksten er, at den samtidig med diskussionen der opbygges, hetjener sig af den kaotiske struktur, der er konsekvensen af diskussionens konklusioner. (Det er også de Mans pointe).

Som en diskussion af sprogets funktion, der nærmest eksplicit lagges op til ved sammenligningen mellem metafor og maleri, kan man sige, at scenen hos Elstir demonterer den bogstavelige mening og fremskriver en anden opfattelse af kunstnerisk skaben end det rent mimetiske forhold mellem verden og det kunstneriske udtryk, som både romanforfatteren og maleren læagger sig opad. Det demonstreres, at verden i maleriet gengives på en måde, der er stærkt drejet efter det medierende subjekts private præferencer. De foretrukne kvaliteter, som maleren søger i verden, søger han, fordi de i forvejen findes i ham, og fordi han ved dem føler en eksistensberettigelse. De kvaliteter han søger og finder, bliver malerens garanter for absolut mening. At det ikke er objektive vardier, ser vi med Marcel, der først oplever Elstirs kone som kedelig og siden, da han har set Elstirs ideal i billederne, finder hende smuk. Idealer, der for maleren kom før konen, og som Marcel ikke ser som iboende kvinden, men Elstir selv.

Marcel oplever begær på forskellige måder og i forskellige sammenhænge. Gilberte og Albertine er objekter for Marcels kærlighed, og det kommer til at påvirke hans liv. Hans kærlighed får ham til at farve verden og drejer hans interesser i retning mod ting, der på den ene eller anden måde er relateret til den elskede. Han tror hver gang, at det er kvaliteter ved kvinderne, der drager ham mod dem. Men teksten viser os, at det hele findes i ham selv. Marcels begar efter erkendelse er ikke altid, som han selv tror, og de erkendelser han intellektuelt når til, er så farvede af hans situation i erkendelsesøjeblikket, at de senere i livet må gøres om, hvis de ikke straks bliver overhalet af den aeldre fortællers retrospektivt organiserede bedreviden. Marcels begar efter $\mathrm{cn}$ sammenhangende og meningsfuld verden organiserer følelser og oplevelser i ham, i den periode hvor han er forelsket i Gilberte. Det sker på trods af, at der ikke er nogen gode grunde til denne sammenhæng i de erfaringer, han gør sig med sin kærlighed.

Perspektivets betydning kommer for alvor frem $\mathrm{i}$ beskrivelsen af billederne hos Elstir, men for laseren, der undervejs skal forholde sig både til historien, som den skrider frem, og til fortællerens refleksioner og konklusioner, bliver det klart, at det betyder meget for oplevelsen af verden, hvordan det begarende subjekt er placeret $\mathrm{i}$ den $\mathrm{i}$ forhold til tiden og rummet og sit begers mål. I Elstirs malerier kan fanomener skubbe sig i forhold til hinanden, således at de ikkc kan placeres i en fornultsmæssig sammenhæng. Ting, der hører til på land, ser ud, som om de er ude i vandet og omvendt. Ting, der på afstand ser små ud, ser store ud tat på. En kirke, man troede stod i et hjørne af byen, kan 
rykkes ind midt i byen ved den rigtige placering af iagttageren. Når Marcel er taet på Albertine, kan han se ti billeder af hende på én gang, og han ved ikke, hvilket der er det rigtige. Når han er forelsket $i$ Gilberte, bliver alt omkring hende overskygget af hende eller relateret til hende, som om hun gav hele verden mening. Perspektivet er vigtigt og har afgørende betydning for perceptionen af verden. Denne betydning kommer til udtryk i maleriet og i sproget under samme vilkår som ved perceptionen.

Sprog og maleri som udtryk for subjektet er underlagt nogle af de samme regler. Der sker de samme forskydninger og farvninger af verden, når man forsøger at give udtryk for en oplevelse af den, hvad enten man taler (fortaller en historie) eller maler. I fortellerens beskrivelse af Elstirs billeder var metaforen bærende. Metaforen gav læseren det perspektiv, som billedbeskueren fik hos Elstir. Vand og land udvekslede kvaliteter efter fortællerens vejledning. Men der er ingen grund til at tro, at denne overførsel skulle være mere neutral, end den maleriet betjener sig af, eller at metaforerne skulle vare tilfaldige.

Marcels begar efter erkendelṣe, kvinder og social prestige făr ham til at gøre en rakke erkendelser i ungdommen. Hver isaer er de måske sande, men han vil tvinge dem alle ind i sammenhæenge, der ligger uden for ham selv, og det er problemet. Erkendelserne er alle styret af begderet, således at det perspektiv, der ligger til grund for dem, er rettet mod verden i et forsøg på at se sine egne sammenæenge $\mathrm{i}$ den. Det syn, der ser landet ligge ude i vandet, kan ikke ophreves til en objektiv sandhedsstatus, men må erkende og forholde sig til sin status som subjektiv erfaring. Når Marcel elsker sine kvinder, søger han ved verbale forklaringer at formulere sine følelser, og ved at give udtryk for dem søger han dem retfærdiggjort hos kvinderne. Det er et umuligt projekt, fordi sproget ikke er rent, men i sig selv danner mening, der kan aflaeses og tolkes af de involverede begærende subjekter. Sammenhangen/meningen er der kun for den enkelte. Sprogets kategoriseringer kan man valge at tro på, som Elstir vaelger at tro på sine idealers objektivitet i alderdommen, eller man kan gøre som Swann, der simpelthen fortriengte de erkendelser, han havde gjort, for at kunne leve med den kvinde han ville elske. En kvinde han vel at marke elskede, før han havde afsløret det skrøbelige betydningssystem, han havde bygget op omkring hende. Derefter viste hun sig ikke at vere hans type. Men der var eller havde varet en sammenhæng og en mening, og den klamrede han sig så til, som også Marcel på et tidspunkt konstaterer, at man gør. Men ARTP lagger i sin struktur op til, at man ikke anerkender nogen overordnet sammenhæeng. Ligesom sproget viser sig at være farvet af begaret efter erkendelse, kvinder og andet, er det det perspektiv, sproget lægger på verden, der på helt afgørende måde problematiseres på fortállingens plan. 
Et karakteristikon ved fortællingen modsat beskrivelsen, er, at det er en temporalt organiseret kxde af relaterede begivenheder. Hvis man forestiller sig, at tiden i verden forløber som en henrinden af sekund pả sekund i et kontinuerligt forløb, hvordan skal man så beskrive dette fxnomen, hvis det karakteristiske ved sproget er, at det deler verden op i enheder og skaber subjektive sammenhange mellem disse, der ikke finder berettigelse for andre end det perciperende og ekspressive subjekt selv? Perspektivet på/i tiden bliver her det afgørende. Hvorfra ses og i hvilken retning? Her kan forfatteren spille på hele registret af udsigelsespositioner. Noget, der markant skiller ARTP ud i forhold til meget andet litteratur, er brugen af synsvinkler og den temporale strukturs uoverskuelighed. ${ }^{41}$

Fortælleren, Marcel som gammel, er den gennemgäende figur, der fortæller historien om Marcels oplevelser, udvikling og erkendelser. Men samtidig med denne historie reflekterer han over handlingen og de tanker, Marcel gør sig undervejs. Den samme begivenhed kan vi få fire gange: hæundelsen beskrives som Marcel oplever den; Marcel reflekterer over handelsen; fortalleren (gen)fortaller haendelsen forskudt fra dens normale tidslige placering; fortielleren reflekterer over hiendelserne, enten samtidig med dem eller forskudt i forhold til dem. Der er ikke nogen oplevelse, refleksion eller erkendelse, der făr lov til at stå uimodsagt på denne måde. Alt kommenteres pả flere planer, og får flere betydninger. Marcels liv, som det fremstilles i ARTP, følger ikke en linie i tiden. Det udvikler sig ikke umiddelbart efter de begivenheder, han gennemlever, men bevager sig mellem en masse punkter, der hver isar giver betydning til det billede, der tegner sig af en person.

Scenen hos Elstir viste, at med hensyn til sproget kan der ikke findes en mening, men kun en tolkning, da subjektet er unikt og helt afgørende, năr man taler om sproget, som billedskabende. På samme måde viser scenen hvor Marcel sent $i$ sit liv besøger Bois de Boulogne, at over tid holder ikke engang sub jektets tolkning, som den er gemt i erindringen. ${ }^{42}$ Det var her, han oplevede starke følelser i forhold til Gilberte og Odette, men tiden er gået og har føjet nye ting til erindringen. Tiden har derved givet alt andet $i$ erindringen en ny mening, hvilket găr op for ham ved besøget. Verden er ikke den samume, og det er hans følelser heller ikke. På grund af følelsernes andrede status er verden ikke den samme, den er forgangelig, selv om dens materialitet forbliver uantastet. Verden er ikke uden for, men inden i Marcel, eller rettere der er en verden begge steder. Når den indre søger en mening $\mathrm{i}$ den ydre, går det galt. Der er noget, der står i vejen. Det er sproget.

Sproget, der lader sig påvirke af subjektets begær og perspektiv, når man taler om perception, erindring og kommunikation, er underlagt vilkår, som det igen pătvinger fortællingen. 


\section{Deleuze}

Flere steder i ARTP diskuterer Marcel sine egne litterære talenter uden optimisme. Han laver en pastiche over en observation af et middagsselskab hos Verdurins, som han tilskriver brødrene Goncourt, forfattere Proust ikke holdt særlig meget af. Den form for litteratur, de bedriver, består i, at forfatteren g $\varnothing \mathbf{r}$ observationer i verden, som han derefter underkaster en causerende analyse. Derigennem når han frem til eksistentielle erkendelser. Det er her Deleuze saetter ind og siger, at den form for litteratur må forkastes, da den lader tegn og indhold vare lig hinanden. ${ }^{43}$ Man tager verden for pålydende, og det kan man ikke. Det er der flere grunde til, og den vigtigste er, at tegnet har to sider. Den ene side er knyttet til det objekt, der har udsendt det; den anden side er gemt $\mathrm{i}$ den person, der opfanger tegnet, og den bygger på en rakke subjektive forudsætninger. I den fortolkendes bevidsthed vil erindringen om andre lignende eller relaterede fanomener, idealer og preferencer spille ind. Verden vil ikke se ens ud for to forskellige mennesker, da tegnet ikke objektivt fortaller om den genstand, der har udsendt det, men skal fortolkes. Dette vilkår, som er basalt for en forståelse af verden, mangler i den litteratur, som Marcel er ked af, at han ikke kan skrive. Det Proust derimod kan, er at gøre denne erfaring til både fundament $o g$ tematisk struktur.

Deleuze siger om varket:

》..objektiviteten kan ikke længere eksistere, undtagen i kunstværket: den eksisterer ikke liengere som et betydende indhold af verdens tilstand, ej heller som en ideal betydning i form af et stabilt indhold, den eksisterer kun i verkets formelle betydningsstruktur, i dets stil. $^{44}$

Det eneste objektive er formen, der behandler den subjektive ytring. Der er ingen essens, kun stil. Et tegn kan ikke vise hele betydningen af en genstand frem, da det ikke indeholder en hel mening. Hvordan laver man så en fortælling om et levet liv, hvis der ingen mening gives at lægge frem, hvis der ikke er noget at fortælle?

Deleuze ser tiden som en række elementer af forskellig størrelse og form, der aldrig har hørt sammen i en enkelt totalitet, da de hver især kommer fra dele af verden, der ikke umiddelbart er sammenhingende. ${ }^{45}$ Subjektet lever $i$ verden og skaber en sammenhæng i tidens elementer, som kun er mulig, hvis det selv erkender det usammenhængende og vil tidens subjektive sammenhæng. Denne sammenhæeng består $\boldsymbol{i}$ værket af en formel del som det eneste konstituerende: 
»Et sådant værk, der har tiden som emne, har ikke brug for at betjene sig af aforismer: det er ved hjælp af snoninger og rundgange at dets antiLogos stil får gjort de nødvendige omveje, der skal til for at samle de yderste fragmenter sammen og feje dem med ved forskellige hastigheder, alle disse stykker, der hver isar henviser til forskellige helheder, til ingen helhed overhovedet eller alene til stilens helhed. $\ll^{46}$

Fortelleren i ARTP er den helhed, der kan findes i vierket. Han er alle de uforenelige størrelser, alle de synsvinkler, der tilsammen er hans liv, som det er beskrevet. Men han er det, uden at de er forenet i en altiorklarende totalitet. Han siger til sidst:

»Jeg havde en følelse af trathed og rædsel, når jeg merkede, at dette spand af tid ikke blot havde varet levet, tankt og udskilt af mig uden afbrydelse, at det var mit liv, at det var mig selv; men endnu mere fordi jeg hvert minut mátte holde det bundet til mig, at det bar mig oppe, at jeg var sat til vejrs på dets svimlende tinde, at jeg ikke kunne bevæge mig uden at tage det med mig. Det tidspunkt hvor jeg hørte den lille klokke i haven i Combray, sâ langt borte og dog stadig i mit indre, var et kendemerke i de valdige udstrakte vidder, jeg ikke vidste, jeg besad. Jeg blev svimmel ved at se så mange år under mig, som om jeg ragede milevidt op i højden. «47

Klokken, han kan høre i sit indre og bruger som pejlemærke, er en barndomserindring, som vi hører om allerede i starten af værket. Dens stadige ringen er beviset for subjektets eksistens i tiden. ${ }^{48}$ Der er noget i Marcel, der har opsamlet tiden. Den er ikke blevet sat ind $\mathbf{i}$ en helhed uden for ham, og heller ikke inden i ham udgør den en helhed. Klokken ringer, som den gjorde den gang, der er ikke sket nogen forvridende mediering endnu. Tiden er stablet op under ham og er uløseligt bundet til ham, som levende stylter, der bliver højere og højere for til sidst at kniekke. ${ }^{19}$

I ARTP er tiden, som den form der danner den eneste mulige ikke-totalitare enhed, skrevet ind som tema og som stilistisk struktur. Den tematiske behandling kredser om sprogets upålidelighed og den forsvundne betydning, der måske genfindes i subjektets temporale eksistens. Den form, der ligger i vierket, gør alt for at få den resterende betydning elimineret. En betydning der kunne være blevet fremskrevet i en kronologisk fortælling, om en mand der spiser kage og derved bringes til at huske sin barndom, som han sætter sig for at beskrive. En fortalling, der uvagerligt ville ende med: Her er jeg, derfor blev jeg, som jeg blev. Som en typisk dannelseshistorie eller selvbiografi der, 
for overhovedet at kunne skrives, forudsætter, at man på forhånd har en ide om, hvordan man er, eller gerne vil være.$^{50}$ En sådan historie ville ikke rumme meget erkendelsespotentiale. Men sådan er det ikke her. I ARTP har fortælleren fralagt sig ethvert ansvar for fortællingens sandfærdighed og troværdighed. Tiden er den eneste form for sammenhæng et menneske kan skabe. Det fär man også en fomemmelse af, når man læser bogen. Det tager tid og det skaber tid.

Paul de Mans læsning af ARTP afslører vilkår på det retoriske plan i teksten, der også kan spores på det tematiske og narratologiske. Ved at anvende hans egen teknik kan man komme meget længere, end han selv gør, men man står følgelig åben og ubeskyttet mod en dekonstruktiv læsning, der tager fat $\mathrm{i}$ tidsbegrebet, og den betydning der lægges i det. Men det må være vigtigere at lave lesninger, der giver nye perspektiver på teksten, end at forsvare en teoretisk position i en grad, der får den til at se ud som tidsfordriv, hvor teoriens redskaber er mål i sig selv. Der sker en betydningsdannelse, selv om den ikke cr baseret på objektivitet og referentialitet, men på læsningen som proces. Det er det vigtigt at holde fast ved.

\section{Noter}

1. Paul De Man: »Reading (Proust) «, in Allegories of Reading, New Haven 1979 (herefter forkortet AR).

2. Gilles Deleuze: Proust and signs, London 1973.

3. Paul De Man : »Semiologi og retorik «, in H. Hauge \& Erslev Andersen (eds.): Tekst og trope, Århus 1988, og Paul de Man.: »The Resistance to Theory« in The Resistance to Theory, Minneapolis 1986.

4. Proust, vol. 2. p. 44-45. Marcel Proust: På Sporet efter den tabte tỉd, vol. 1-13, Kbh. 1932-8. Når jeg i noteme henviser til ARTP, er det denne danske udgave, jeg tanker på, medmindre andet er anf $\varnothing$ it.

5. Op.cit., vol 1, pp. 68-9.

6. Op.cit., vol. 1, pp. 152-3 og p. 164.

7. Op.cit., vol. 1, pp. 182-222.

8. Op.cit, vol. 1, p. 216.

9. Op.cit., vol. 1, p. 45.

10. Op.cit., vol. 1, p. 218.

11. Se også kapitel 1 i David Ellison; The Reading of Proust, Baltimore 1984.

12. Op.cil., vol. 2, pp. $221-2$.

13. Op.cit., vol. 2 , p. 39.

14. Op.cit., vol. 2, p. 222, den danske oversatter har oversat »table tournante《 med »spiritistisk borddans«; denne oversættelse giver derfor ikke mulighed for denne tolkning.

15. Op.cit., vol. 2, p. 222.

16. Op.cit., vol. 2, pp. 235-6. 
17. Op.cit., vol. 2, p. 260.

18. Mødel med Elstir vender jeg tilbage til. I artiklen kalder jeg for tremheds skyld hovedpersonen og jeg-fortælleren for Marcel, selv om hans navn kun næunes to gange i løbet af hele varket.

19. Paul de Man skylder Gérard Genette en del, når han i sine analyscr viser, hvorledes metaforer snarere er metonymier, end metaforer. Se f.eks. Gérard Genette : »Mctonymie chez Proust i Figures III, pp. 41-63, Paris 1972.

20. AR, p. 57.

21. Loc.cit., pp. 58-62.

22. Loc.cit., pp. 62-7.

23. Loc.cit., pp. 70-2.

24. Loc.cit., pp. 72-3.

25. Loc.cit., pp. 73-6.

26. Loc.cit., pp. 76-7.

27. Op.cit., vol. 1, p. 51.

28. Op.cit, vol. 1, pp. 51-55.

29. Op.cit, vol. 1, pp. 161-165.

30. Op.cit., vol. 1, p. 163.

31. Op.cit., vol. 1, p. 163.

32. Op.cit., vol. 1, p. 164.

33. Op.cit., vol. 1, p. 165.

34. Op.cit., vol. 1, p. 165.

35. Op.cit., vol. 1, p. 246.

36. Op.cit., vol. 1, p. 247.

37. Marcel Proust: A la Recherche du Temps Perdu, Paris 1988. Vol. 1-7., A l'ombre des jeunes filles en fleurs, p. 399. Oversxttelserne fra fransk or mine egne, men jeg har konsulteret den danske oversættelse al varket. Den franske tekst er citerct i noterne. $\gg$ Mais i'y pouvais discemer que le charme de chacune consistait en une sorte de métamorphose des choses représentées, analogue à celle qu'en poésic on nomme métaphore et çue si Dicu le Père avait créć les choses en nommant, c'est cn leur ôtant leur nom, ou en leur donnant un autre qu'Elstir les recréait.«

38. Proust: A l'ombre des jeunes filles' en fleurs, p. 400. »Mais les rares moments oú l'on voit la nature tclle qu'elle est, poétiquement, c'ćtait de ceux-lá qu'était faite l'oeuvre d'Elstir.«

39. Op.cit., vol. i p. 267.

40. Proust: A l'ombre des' jeunes filles en fleurs, p. 415. ». la beauté de la vie, mot en quelque sorte dépourvu de signification, stade situé cn deça de l'art et auquel j'avais vu s'arrêter Swann, était celui oú par ralentisscment du génic créateur, idolâtrie des formes qui l'avaient favorisé, désir du moindre effort, dcvait un jour rétrograder peu à peu un Elstir.«

41. Se f.eks. Gerard Genette: Narrative Discourse, New York 1980.

42. Op.cit., vol. 1, pp. 310-16. Marcel tager til Bois de Boulogne og går pả de sticr, hvor han i sin tid, mens han var forelsket i Gilberte, gik tur for at lia et glimt af hendes mor Odette, der kommer til at personificere femininitet og elegance. Følelseme for Odette, som måske var afledt af kærligheden til Gilberte, er knyttet sả starkt til stedet, at nogle al dem vekkes ved bes $\varnothing$ get.

43. Op.cit., pp. 31 -3, se også Proust: Contre Sainte-Beuve, Paris 1992.

44. Op.cit., p. 99, oversiettelserne af Deleuze fra den engclske udgave er mine egne. »... objectivity can no longer exist except in the work of art: it no longer exists in 
significant content as states of the world, nor in ideal signification as stable essence, but solely in the signifying formal structure of the work, in its style.«

45. Op.cit., pp. 101-2.

46. Op.cit., pp. 102-3. »Such a work, having for subject time itself, has no need to write by aphorisms: it is in the meanders and rings of an anti-Logos style that it makes the requisite detours in order to gather up the ultimate fragments, to sweep along at different speeds all the pieces, each one of which refers to a different whole, to no whole at all, or to no other whole than that of style.«

47. Proust: Le Temps retrouvé, p. 352 (varkets næstsidste side): "J'éprouvais un sentiment de fatigue et d'effroi à sentir que tout ce temps si long non seulement avait, sans une interruption, été vecu, pensé, sécrété par moi, qu'il était ma vie, qu'il était moi-même, mais encore que j'avais à toute minute à le maintenir attaché à moi, qu'il me supportait, moi, juché à son sommet vertigineux, que je ne pouvais me mouvoir sans le déplacer comme je le pouvais avec lui. La date à laquelle j'entendais le bruit de la sonnette du jardin de Combray, si distant et pourtant intérieur, était un point de repère dans cette dimension énorme que je ne me savais pas avoir. J'avais le vertige de voir au-dessous de moi, en moi pourtant, comme si j'avais des lieues de hauteur, tant d'années. «

48. Proust: Du côté de chez Swann, pp. 13-4. Om klokken, se også Claudia Brodsky: The Imposition of Form, Princeton 1987.

49. Proust: Le Temps retrouvé, p. 353.

50. ARTP er ofte, p.g.a. jeg-fortælleren og formen, der med de mange ana- og prolepser ligner fremstillingen af en bevisrakke, blevet last som en selvbiografi. 